\title{
Pregnancy-induced adaptations of the central circadian clock and maternal glucocorticoids
}

Michaela D Wharfe', Peter J Mark', Caitlin S Wyrwoll', Jeremy T Smith', Cassandra Yap', Michael W Clarke ${ }^{2}$ and Brendan J Waddell ${ }^{1}$

${ }^{1}$ School of Anatomy, Physiology and Human Biology, The University of Western Australia, M309, Perth 6009, Australia

${ }^{2}$ Metabolomics Australia, The University of Western Australia, Perth 6009, Australia
Correspondence should be addressed to B J Waddell Email brendan.waddell@ uwa.edu.au

\begin{abstract}
Maternal physiological adaptations, such as changes to the hypothalamic-pituitary-adrenal (HPA) axis, are central to pregnancy success. Circadian variation of the HPA axis is dependent on clock gene rhythms in the hypothalamus, but it is not known whether pregnancy-induced changes in maternal glucocorticoid levels are mediated via this central clock. We hypothesized that hypothalamic expression of clock genes changes across mouse pregnancy and this is linked to altered HPA activity. The anterior hypothalamus and maternal plasma were collected from C57BI/6J mice prior to pregnancy and on days 6, 10, 14 and 18 of gestation (term =d19), across a 24-h period (0800, 1200, 1600, 2000, 0000, $0400 \mathrm{~h}$ ).

Hypothalamic expression of clock genes and $\mathrm{Crh}$ was determined by qPCR, plasma ACTH concentration measured by Milliplex assay and plasma corticosterone concentration by LC-MS/MS. Expression of all clock genes varied markedly across gestation, most notably at mid-gestation when levels of each gene were elevated. The pregnancy-induced increase in maternal corticosterone levels (by up to 14-fold on day 14) was not accompanied by a parallel shift in plasma ACTH (28\% lower on day 14 compared with non-pregnant levels). Moreover, while circadian rhythmicity in corticosterone was maintained up to day 14 of gestation, this was effectively lost by day 18 . Overall, our data show that the central circadian clock undergoes marked adaptations throughout mouse pregnancy, changes that are likely to contribute to maternal physiological adaptations. Importantly, however, neither hypothalamic clock genes nor plasma ACTH levels appear to drive the marked increase in maternal corticosterone after mid-gestation.
\end{abstract}
Key Words
- circadian
- clock genes
- glucocorticoids
- pregnancy

Journal of Endocrinology (2016) 228, 135-147

\section{Introduction}

Maternal physiological adaptations are central to pregnancy success, balancing fetal and placental demands with the maintenance of maternal homeostasis. Among these maternal adaptations, enhanced activity of the hypothalamic-pituitary-adrenal (HPA) axis after midgestation leads to increased glucocorticoid levels (Patrick et al. 1980, Atkinson \& Waddell 1995). This HPA axis adaptation is crucial because it promotes the release of energy stores to meet high fetal demand (Atkinson \& Waddell 1995), yet the regulation of HPA axis function in pregnancy remains poorly understood. The HPA axis is driven principally by corticotropin-releasing hormone

Published by Bioscientifica Ltd 
(CRH) released from the paraventricular nucleus (PVN), which stimulates pituitary secretion of adrenocorticotropic hormone (ACTH). ACTH, in turn, stimulates adrenocortical secretion of glucocorticoids (cortisol in humans and corticosterone in rodents), which exert negative feedback effects at the hypothalamus and pituitary (Spiga et al. 2014). In pregnancy, the placenta may also provide direct trophic support to stimulate adrenal glucocorticoid secretion (Waddell 1993, Waddell \& Burton 1993).

An additional feature of HPA axis function is its robust circadian variation, driven in part by the rhythmic expression of clock genes in the suprachiasmatic nucleus (SCN) (Nader et al. 2010). These clock genes (Bmal1/Arntl, Clock, Per1, Per2, Cry1 and Cry2) form a molecular network of transcriptional-translational loops to drive their own rhythmic expression and that of downstream targets including CRH (via efferent projections from the SCN to the PVN) (Nader et al. 2010). In the core oscillatory loop, a CLOCK-BMAL1 protein heterodimer activates the transcription of Per and Cry genes. This is followed several hours later by an accumulation of PER and CRY proteins, which form complexes in the cytoplasm. These complexes translocate to the nucleus where they associate with the CLOCK-BMAL1 heterodimer and thereby inhibit the transcription of Per and Cry genes. The resultant fall in the expression of PER and CRY removes their negative feedback and the cycle is reinitiated. An accessory loop involves two transcription factors, Rev-erb $\alpha$ and Ror $\alpha$, which have opposite effects on Bmal1 transcription (inhibitory and stimulatory respectively) (Hastings et al. 2007).

In addition to this central clock, circadian variation in physiology is mediated via similar clock gene networks in key metabolic tissues, referred to as 'peripheral clocks'. The circadian rhythm of circulating glucocorticoids (generated via the HPA axis) provides a key coordination link between the central SCN clock and these peripheral clocks (Hastings et al. 2007), and as such plays a crucial role in overall metabolic homeostasis. Accordingly, changes in clock gene networks likely mediate maternal physiological adaptations to pregnancy. One previous report has shown that peak PER2 expression in the SCN was phase advanced by 4 -h on day 6 of gestation in the rat (Schrader et al. 2010). Whether pregnancy also alters the expression of other clock genes, or whether such changes influence downstream physiology including the HPA axis, is unknown. Such changes may have important implications for pregnancy success, since circadian disruption is known to adversely affect fetal growth and developmental programming outcomes (Varcoe et al. 2011). Therefore, in this study, we tested the hypothesis that hypothalamic expression of clock genes changes with the onset and progression of pregnancy, and that these changes are linked to altered HPA activity. Hypothalamic expression of clock genes and $\mathrm{Crh}$ and plasma ACTH and corticosterone levels was measured at six time points across the circadian day in the non-pregnant female mouse and on days 6,10 , 14 and 18 of mouse pregnancy.

\section{Materials and methods}

\section{Animals}

Nulliparous C57Bl/6J mice (6-9 weeks old) were supplied by the Animal Resources Centre (Murdoch, Australia). All procedures involving the use of animals were conducted after approval by the Animal Ethics Committee of the University of Western Australia (AEC no. RA/3/100/1070). Mice were maintained in two environmentally controlled rooms, with food and water supplied ad libitum. In one room, mice were exposed to a normal $12 \mathrm{~h}$ light: $12 \mathrm{~h}$ darkness cycle (lights on at $0700 \mathrm{~h}$ ); in the other room, the light cycle was reversed (lights on for $12 \mathrm{~h}$ from $1900 \mathrm{~h}$ ). Between 0700 and $1900 \mathrm{~h}$, these mice were exposed to a constant red light $(36 \mathrm{~W}, 620 \mathrm{~nm})$. Preliminary studies showed no effect of exposure to red light on clock gene expression (unpublished observations). Both groups of animals were allowed to acclimatize to their respective light cycle for 2 weeks before any experimental procedures were conducted. Lights on at $0700 \mathrm{~h}$ (or $1900 \mathrm{~h}$ in the reverse-light room) was classified as a new day and as zeitgeber time (ZT)0, and sampling times were defined relative to ZTO. Female mice were mated overnight, and pregnancy was confirmed by visualization of a mucous plug the following morning (designated day 1 of pregnancy). In a separate group of non-pregnant mice, cycle stage was monitored for a minimum of three full estrous cycles by vaginal lavage (between ZT6 and ZT13) by the protocol of Caligioni (2009). Animals with irregular cycles were excluded.

\section{Tissue collection}

Tissues and plasma were collected from mice under isoflurane/nitrous oxide anesthesia (0.2:0.8) at $4 \mathrm{~h}$ intervals commencing at ZT1 on either diestrus I of the cycle or day $6,10,14$ or 18 of pregnancy (term=day 19). For collection of tissues in the dark phase, mice were anesthetized under red light and then covered with a

Published by Bioscientifica Ltd 
lightproof hood before collection of tissues under white light. A blood sample was collected from all mice under anesthesia by cardiac puncture (into an EDTA tube), and the whole brain was collected and frozen on crushed dry ice. Maternal blood was centrifuged and plasma and the brain stored at $-80^{\circ} \mathrm{C}$.

\section{RNA sample preparation}

Dissection of the anterior hypothalamus was carried out on dry ice, according to the protocol of Quennell et al. (2011). Total RNA was extracted from the anterior hypothalamus using QIAzol (Qiagen), according to the manufacturer's instructions. RNA was quantified using the Nanodrop ND-1000 spectrophotometer (Thermo Scientific, Wilmington, DE, USA) at $260 \mathrm{~nm}$, before $1 \mu \mathrm{g}$ of total RNA was reverse transcribed at $42^{\circ} \mathrm{C}$ for $110 \mathrm{~min}$ by Mouse Moloney leukemia virus reverse transcriptase with random hexamers (Promega). The resultant cDNAs were purified using an ultra-clean PCR spin kit (MoBio Laboratories, Inc., Carlsbad, CA, USA), according to the manufacturer's instructions.

\section{Real-time PCR}

Analyses of mRNA expression levels for Clock, Arntl (which encodes for Bmal1), Per1, Per2, Cry1, Cry2, Nr1d1 (which encodes for Rev-erb $\alpha$ ), Ror $\alpha$, Crh and the reference genes succinate dehydrogenase subunit A (Sdha), hypoxanthineguanine phosphoribosyltransferase (Hprt) and beta actin $(A c t b)$ were performed by real-time PCR on the Rotorgene 6000 system (Corbett Research, Sydney, Australia). Primer pairs for all these genes (see Table 1) were designed using Primer-BLAST (http://www.ncbi.nlm.nih.gov). All primer pairs were designed to span introns to prevent amplification of products from genomic DNA. The resulting amplicons were separated on $1.5 \%$ agarose gel containing ethidium bromide and sequenced to confirm specificity. Standard curves were created with tenfold serial dilutions of gel-extracted (QIAEXII: Qiagen) PCR products and using the Rotorgene 6000 software. All samples were normalized against Sdha, Hprt and Actb using the GeNorm algorithm (Vandesompele et al. 2002).

\section{Measurement of plasma corticosterone and 11-dehydrocorticosterone}

Plasma corticosterone and 11-dehydrocorticosterone (11-DHC) concentrations were analyzed using liquid chromatography tandem mass spectrometry (LC-MS/MS). The internal standard (IS) for both metabolites was cortisol d4. Briefly, $50 \mu \mathrm{l}$ of IS $(50 \mathrm{ng} / \mathrm{ml})$ were added to $50 \mu \mathrm{l}$ of plasma or standard and subsequently vortexed in a glass

Table 1 PCR conditions

\begin{tabular}{|c|c|c|c|c|}
\hline Gene & Forward/reverse primer sequence & $\begin{array}{l}\text { Amplicon } \\
\text { size (bp) }\end{array}$ & $\begin{array}{c}\text { Annealing } \\
\text { temperature }\left({ }^{\circ} \mathrm{C}\right)\end{array}$ & $\begin{array}{r}\mathbf{M g C l}_{\mathbf{2}} \\
(\mathrm{mM})\end{array}$ \\
\hline Clock & $\begin{array}{l}\text { F: } 5^{\prime} \text {-ACAACGCACACATAGGCCTTC-3' } \\
\text { R: } 5^{\prime}-\text { TGGTGGTGCCCTGTGATCTA-3' }\end{array}$ & 175 & 60 & 3 \\
\hline Bmal1 & $\begin{array}{l}\text { F: } 5^{\prime}-\text { CGTGCTAAGGATGGCTGTTC- } 3^{\prime} \\
\text { R: } 5^{\prime}-C T T C C C T C G G T C A C A T C C T A-3^{\prime}\end{array}$ & 166 & 60 & 3 \\
\hline Per1 & $\begin{array}{l}\text { F: } 5^{\prime}-\text { TGCACTTCGGGAGCTCAAACTTC-3' } \\
\text { R: } 5^{\prime} \text {-GTCCATGGCACAAGGCTCACC-3' }\end{array}$ & 169 & 59 & 2 \\
\hline Per2 & $\begin{array}{l}\text { F: 5'-AACAAATCCACCGGC-3' } \\
\text { R: } 5^{\prime}-\text { CTCCGGTGAGACTCC-3' }\end{array}$ & 145 & 60 & 3 \\
\hline Cry1 & $\begin{array}{l}\text { F: 5'-AACGTCCCGAGCTGTAGCGGT-3' } \\
\text { R: } 5^{\prime}-\text { GACGCTTCCCACTGCTGAGGC-3' }\end{array}$ & 139 & 60 & 2 \\
\hline Cry2 & $\begin{array}{l}\text { F: 5'-TGCCTCTCCTGCCGCCTCTT-3' } \\
\text { R: 5'-TGCGGTCCCAGGGGATCTGG-3' }\end{array}$ & 193 & 60 & 2 \\
\hline Rev-erb $\alpha$ & $\begin{array}{l}\text { F: 5'-CGGGGCTCACTCGTCTCCCT-3' } \\
\text { R: } 5^{\prime} \text {-GCTCGGGGAGGAGCCACTAGA-3' }\end{array}$ & 185 & 60 & 2 \\
\hline $\operatorname{Ror} \alpha$ & $\begin{array}{l}\text { F: 5'-CCCAACCGTGTCCATGGCAG-3' } \\
\text { R: } 5^{\prime}-\text { TCCATCAATGCGTTTGGCAA-3' }\end{array}$ & 235 & 60 & 3 \\
\hline Crh & $\begin{array}{l}\text { F: 5'-AGGCATCCTGAGAGAAGTCC-3' } \\
\text { R: 5'-ACGACAGAGCCACCAGCAG-3' }\end{array}$ & 186 & 58 & 2 \\
\hline Actb & $\begin{array}{l}\text { F: 5'-TCCACACCCGCCACCAG-3' } \\
\text { R: } 5^{\prime}-\text { GGCCTCGTCACCCACATAG-3' }\end{array}$ & 197 & 58 & 2 \\
\hline Hprt & $\begin{array}{l}\text { F: 5'-GCAGTACAGCCCCAAAATGG-3' } \\
\text { R: } 5^{\prime}-\text { AGTCTGGCCTGTATCCAACAC-3' }\end{array}$ & 80 & 58 & 2 \\
\hline Sdha & $\begin{array}{l}\text { F: } 5^{\prime}-\text { TGGGGAGTGCCGTGGTGTCA-3' } \\
\text { R: } 5^{\prime}-\text { CTGTGCCGTCCCCTGTGCTG-3 }\end{array}$ & 149 & 60 & 2 \\
\hline
\end{tabular}

(c) 2016 Society for Endocrinology Printed in Great Britain 
tube. Steroids were extracted with methyl tertiary butyl ether $(1 \mathrm{ml})$ by vigorous vortexing. The supernatant was transferred into an ultra-performance liquid chromatography (UPLC) injector vial, and then dried in a centrifugal vacuum evaporator. The analytes were resuspended in $70 \mu \mathrm{l}$ of mobile phase $(70 \%$ methanol, $0.1 \%$ formic acid and $29.9 \%$ water) before heating at $50{ }^{\circ} \mathrm{C}$ for $10 \mathrm{~min}$. The sample $(20 \mu \mathrm{l})$ was injected onto an Agilent 6460 Triple Quadrupole mass spectrometer system coupled to $2 \times 1290$ UPLC series LC pumps. The LC system was run in 2D mode, consisting of two columns: the first was an Agilent Poroshell 120 EC-C18, 2.7um, $2.1 \times 50 \mathrm{~mm}$ column (Agilent Technologies, Santa Clara, CA, USA); the second was a Phenomenex Kinetex C18, $2.6 \mu \mathrm{m}, 3.0 \times 150 \mathrm{~mm}$ column (Torrance, CA, USA). The mobile phase flow rate was $0.2 \mathrm{ml} / \mathrm{min}$ through both columns, and molecules were 'heart cut' from column 1 to column 2 within a 1-2 min time window. The instrument was operated in positive ionization mode. Assay precision was assessed during each batch by spiking EDTA plasma with compounds of interest, which were then used as quality controls. Intra- and inter-assay coefficients of variation $(\mathrm{CV})$ for corticosterone were $1.4 \%$ and $3.2 \%$ respectively, and for 11-DHC were 9.7 and $17.5 \%$.

\section{Measurement of plasma ACTH}

Plasma ACTH concentrations were measured using a Milliplex Map assay kit (Cat\#MADKMAG-49K; Merck Millipore, MA, USA). Samples were centrifuged at $13000 \mathrm{~g}$ for $5 \mathrm{~min}$ prior to analysis. The assay was performed according to the manufacturer's instructions. Plates were read using a MAGPIX plate reader and analyzed using xPONENT Software (Merck Millipore). Intra- and inter-assay CV for ACTH were 3.9 and 7.4\% respectively. Values are expressed as $\mathrm{pg} / \mathrm{ml}$.

\section{Statistical analysis}

All data are expressed as mean \pm s.E.M., with 6-8 mice per ZT on each day of pregnancy. Where data were not normally distributed (based on D'Agostino and Pearson omnibus normality test), values were log transformed prior to statistical analysis. Two-way ANOVA was used to compare hypothalamic clock gene expression in nonpregnant and pregnant mice (with time of day and pregnancy stage as factors). When a significant interaction was observed, time-of-day variation within each day was assessed by one-way ANOVA.

Circadian rhythms were assessed by cosinor analysis using a nonlinear regression model (Genstat Version 9,
VSN International Ltd, Hemel Hempstead, UK). The analysis generated the following rhythm descriptors: mesor (circadian rhythm-adjusted mean), amplitude, acrophase (time of the peak of a rhythm) and cosinor $r^{2}$. One-way ANOVA (GraphPad Prism 6.0, San Diego, CA, USA) was used to determine whether each of these cosinor descriptors varied with stage of pregnancy. For all ANOVAs, where the $F$ test was significant $(P<0.05)$, post hoc LSD tests were used for pairwise comparisons. Relationships among corticosterone, clock genes and ACTH were assessed by linear regression analysis (GraphPad Prism 6.0).

For all results, differences attributable to time of day and day of pregnancy assessed by ANOVA are presented first. Where there is a significant effect of time, subsequent cosinor analyses are presented to determine the impact of day of pregnancy on circadian characteristics.

\section{Results}

\section{Hypothalamic clock gene expression}

Hypothalamic expression of all clock genes, with the exception of Ror $\alpha$, varied with time of day $(P<0.001$, ANOVA) and stage of pregnancy ( $P<0.001$; Figs 1 and 2$)$. Significant interactions between time of day and stage of pregnancy were evident for Bmal1 $(P<0.001)$, Cry1 $(P<0.001)$ and Rev-erb $\alpha(P<0.05)$, indicating that pregnancy influenced the circadian expression of these clock genes.

Cosinor analysis revealed highly significant circadian variation for hypothalamic expression of all clock genes, again with the exception of Ror $\alpha$ (see Table 2 for $r^{2}$ and $P$ values). The resultant circadian characteristics (mesor, amplitude and acrophase) for clock gene expression across pregnancy are presented in Table 3. A common feature observed among all the clock genes was elevated overall expression (i.e. mesor increased by up to 1.5 -fold) by day 10 of pregnancy (Figs 1 and 2), consistent with the ANOVA data. The overall expression of Bmal1, Per2 and Rev-erb $\alpha$ remained elevated beyond mid-pregnancy, whereas mesor levels for Clock, Cry1 and Cry2 fell by day 14 before increasing again near term (day 18). Interestingly, the amplitude of the Rev-erb $\alpha$ profile had increased by day 10 but then returned to pre-pregnancy levels by day 18 , whereas amplitudes remained unchanged across pregnancy for all the other clock genes (Fig. 2). Finally, hypothalamic expression of Per1 fell slightly with the onset and progression of pregnancy apart from a transient rise on day 10.

Published by Bioscientifica Ltd 

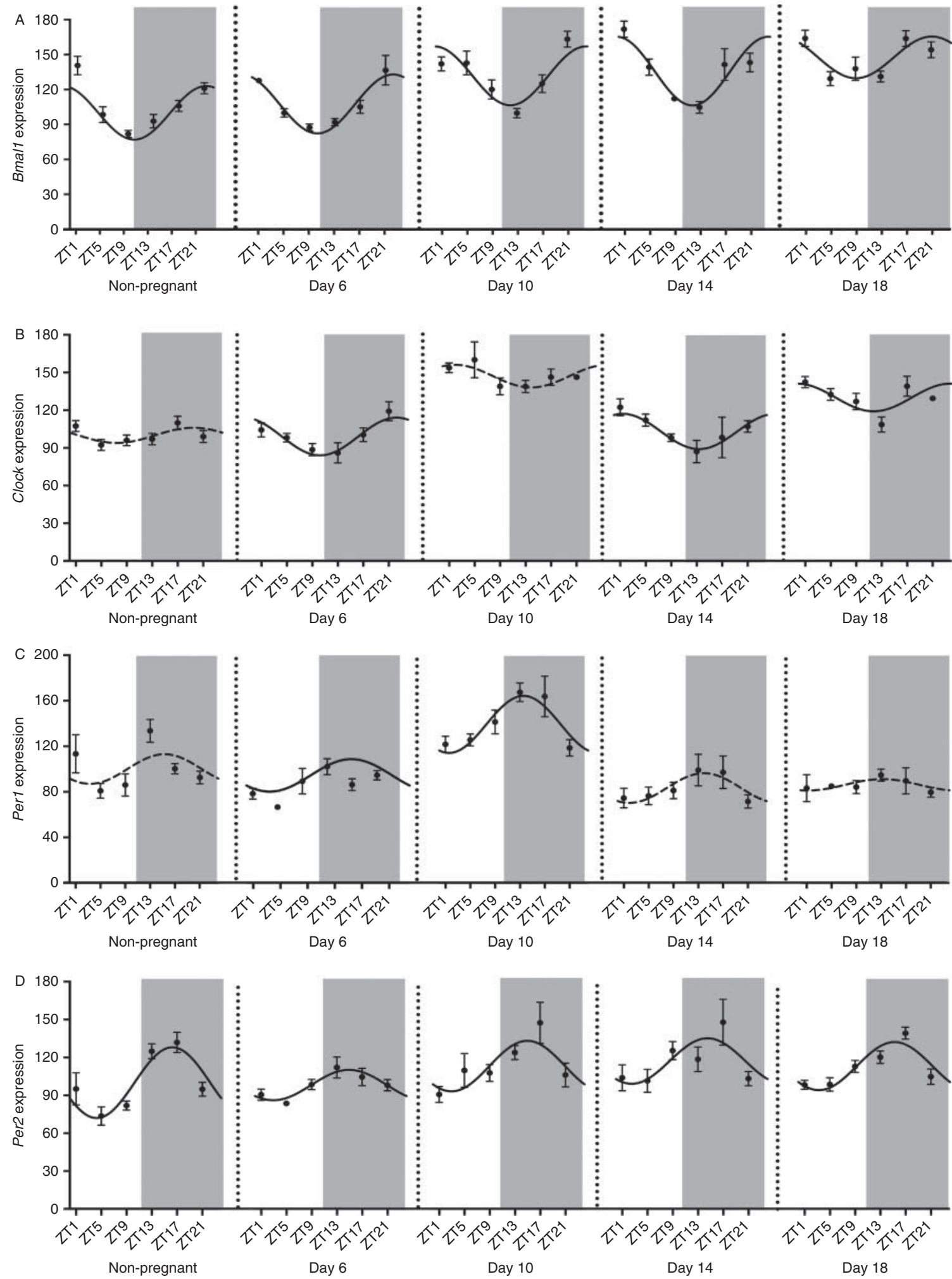

Figure 1

Hypothalamic expression of (A) Bmal1, (B) Clock, (C) Per1 and (D) Per2 at ZT1, ZT5, ZT9, ZT13, ZT17 and ZT21 in non-pregnant and pregnant mice on days $6,10,14$ and 18 . Values are mean \pm s.E.M. ( $n=6-8$ /group). Gray shading Printed in Great Britain represents the dark phase of the light cycle. The best-fit curve derived from cosinor analysis is shown as a solid line when significant $(P<0.05)$ and as a dashed line when non-significant. 


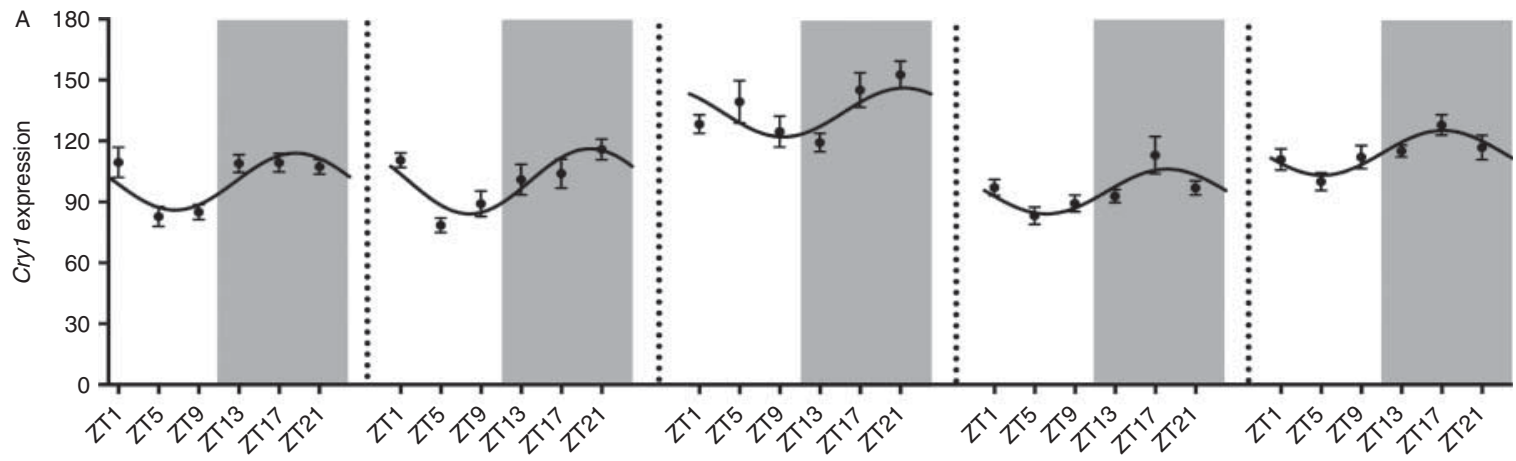

Non-pregnant

Day 6

Day 10

Day 14

Day 18

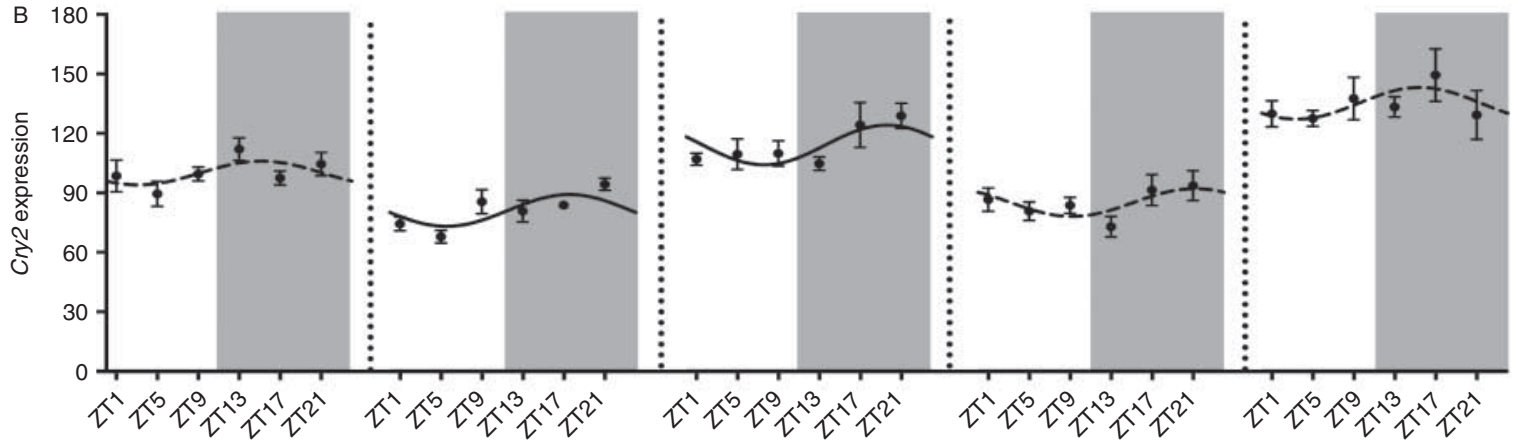

Non-pregnant

Day 6

Day 10

Day 14

Day 18

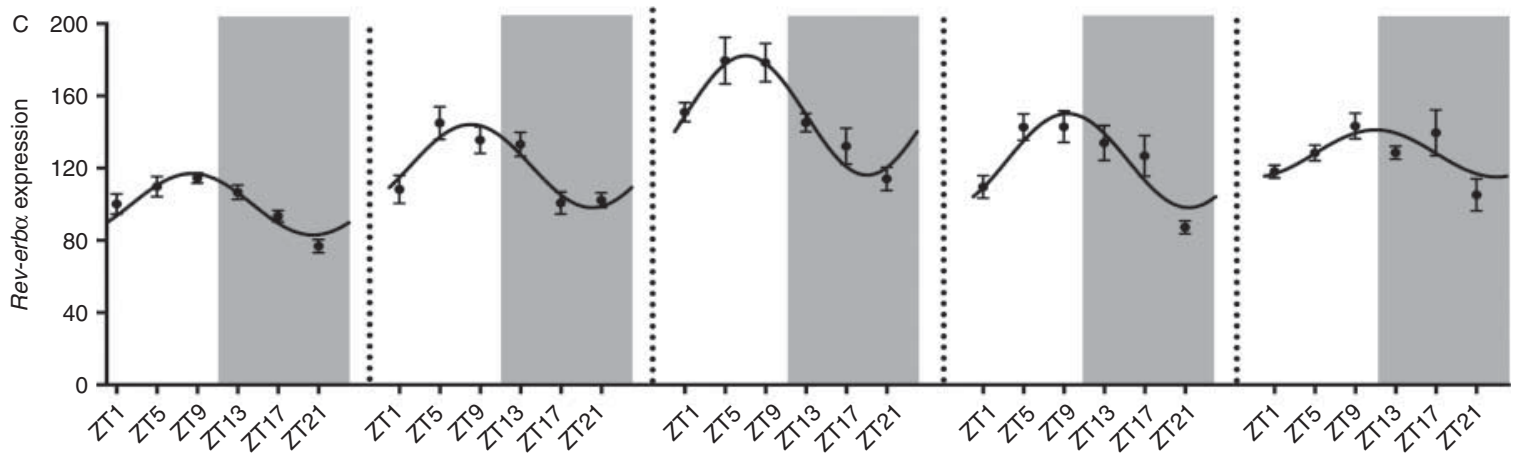

Non-pregnant

Day 6

Day 10

Day 14

Day 18

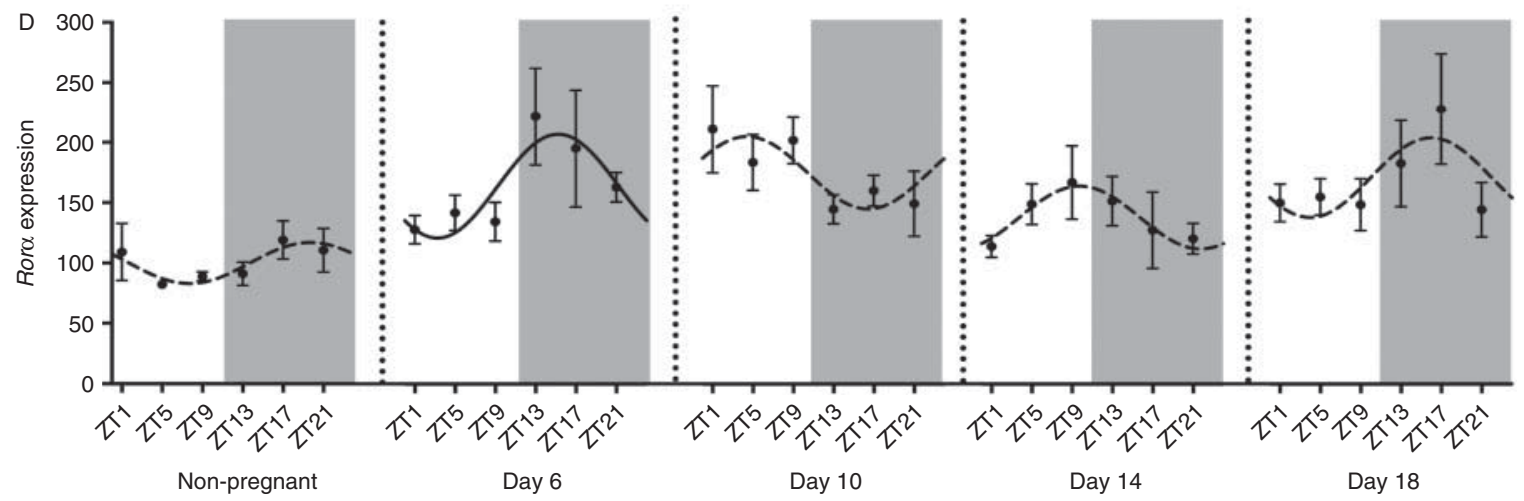

Figure 2

Hypothalamic expression of (A) Cry1, (B) Cry2, (C) Rev-erb $\alpha$ and (D) Ror $\alpha$ at ZT1, ZT5, ZT9, ZT13, ZT17 and ZT21 in non-pregnant and pregnant mice on days $6,10,14$ and 18 . Values are mean \pm s.E.M. ( $n=6-8 /$ group). Gray shading Printed in Great Britain represents the dark phase of the light cycle. The best-fit curve derived from cosinor analysis is shown as a solid line when significant $(P<0.05)$ and as a dashed line when non-significant. 
Table 2 Values of $r^{2}$ derived from cosinor analyses of anterior hypothalamic clock gene expression

\begin{tabular}{l} 
Gene \\
\hline Bmal1 \\
Clock \\
Per1 \\
Per2 \\
Cry1 \\
Cry2 \\
Rev-erb $\alpha$ \\
Ror $\alpha$ \\
\hline
\end{tabular}

\begin{tabular}{l}
\hline \multicolumn{1}{c}{ Non-pregnant } \\
\hline $0.556(P<0.0001)$ \\
$0.071(\mathrm{NS})$ \\
$0.066(\mathrm{NS})$ \\
$0.496(P<0.0001)$ \\
$0.364(P<0.0001)$ \\
$0.044(\mathrm{NS})$ \\
$0.546(P<0.0001)$ \\
$0.083(\mathrm{NS})$ \\
\hline
\end{tabular}

\begin{tabular}{l}
\hline \multicolumn{1}{c}{ Day 6} \\
\hline $0.529(P<0.0001)$ \\
$0.304(P<0.001)$ \\
$0.190(P<0.05)$ \\
$0.278(P<0.001)$ \\
$0.333(P<0.0001)$ \\
$0.159(P<0.05)$ \\
$0.461(P<0.0001)$ \\
$0.127(P<0.05)$ \\
\hline
\end{tabular}

\begin{tabular}{l}
\multicolumn{1}{c}{ Day 10 } \\
\hline $0.445(P<0.0001)$ \\
$0.069(\mathrm{NS})$ \\
$0.342(P<0.0001)$ \\
$0.196(P<0.05)$ \\
$0.127(P<0.05)$ \\
$0.107(P<0.05)$ \\
$0.525(P<0.0001)$ \\
$0.061(\mathrm{NS})$
\end{tabular}

\begin{tabular}{l}
\multicolumn{1}{c}{ Day 14 } \\
\hline $0.474(P<0.0001)$ \\
$0.166(P<0.05)$ \\
$0.092(P=0.068)$ \\
$0.146(P<0.05)$ \\
$0.243(P<0.05)$ \\
$0.055(N S)$ \\
$0.414(P<0.0001)$ \\
$0.073(N S)$
\end{tabular}

\begin{tabular}{l}
\multicolumn{1}{c}{ Day 18 } \\
\hline $0.267(P=0.0011)$ \\
$0.162(P<0.05)$ \\
\multicolumn{1}{c}{$0(\mathrm{NS})$} \\
$0.497(P<0.0001)$ \\
$0.267(P<0.05)$ \\
$0.004(\mathrm{NS})$ \\
$0.143(P<0.05)$ \\
$0.051(\mathrm{NS})$ \\
\hline
\end{tabular}

Relevant $P$ values are shown in parentheses unless non-significant (NS).

For the majority of the clock genes, the time of peak expression (acrophase) showed little change across pregnancy (Figs 1 and 2). The key exceptions were a 3-h phase advance for Bmal1 between days 14 and $18(P<0.05)$ and a delay in the acrophase of Rev-erb $\alpha$, which occurred later in the day with the progression of pregnancy, shifting from approximately ZT8 in non-pregnant mice to ZT11 by day 18 of pregnancy $(P<0.05)$.

\section{Hypothalamic Crh expression}

Surprisingly, Crh expression in the hypothalamus showed only a trend for variation with time of day $(P=0.056$,
ANOVA) but did vary markedly with stage of pregnancy $(P<0.001$; Fig. 3A). Post hoc analysis demonstrated a clear peak in the overall expression of $\mathrm{Crh}$ on day 10 of pregnancy followed by a decline to non-pregnant levels on days 14 and 18. Consistent with the absence of significant time-of-day variation (by ANOVA), cosinor analysis of $\mathrm{Crh}$ expression showed no significant rhythmic variation at any stage (see Table 4 for $r^{2}$ and $P$ values).

\section{Plasma ACTH}

Plasma ACTH levels varied significantly with time of day $(P<0.05$, ANOVA $)$ and stage of pregnancy $(P<0.0001)$,

Table 3 Mesor, amplitude and acrophase derived from cosinor analyses of anterior hypothalamic clock gene expression

\begin{tabular}{|c|c|c|c|c|c|c|c|}
\hline Gene & & Non-pregnant & Day 6 & Day 10 & Day 14 & Day 18 & $\boldsymbol{P}$ \\
\hline \multirow[t]{3}{*}{ Bmal1 } & Mesor & $100 \pm 2^{a}$ & $102 \pm 3^{a}$ & $125 \pm 3^{b}$ & $129 \pm 3^{b}$ & $140 \pm 3^{c}$ & $<0.0001$ \\
\hline & Amplitude & $23 \pm 3$ & $24 \pm 4$ & $24 \pm 4$ & $28 \pm 5$ & $17 \pm 4$ & NS \\
\hline & Acrophase & $22.8 \pm 0.5^{a, c}$ & $22.4 \pm 0.6^{a, c}$ & $23.8 \pm 0.7^{b, c}$ & $23.7 \pm 0.6^{b, c}$ & $20.4 \pm 0.9^{a}$ & $<0.05$ \\
\hline \multirow[t]{3}{*}{ Clock } & Mesor & $100 \pm 2^{a}$ & $99 \pm 2^{a}$ & $147 \pm 3^{b}$ & $103 \pm 3^{a}$ & $130 \pm 3^{c}$ & $<0.0001$ \\
\hline & Amplitude & - & $15 \pm 3$ & - & $14 \pm 5$ & $11 \pm 4$ & NS \\
\hline & Acrophase & - & $22.2 \pm 0.9$ & - & $25.4 \pm 1.3$ & $23.8 \pm 2.5$ & NS \\
\hline \multirow[t]{3}{*}{ Per1 } & Mesor & $100 \pm 4^{a}$ & $86 \pm 3^{b}$ & $139 \pm 4^{c}$ & $83 \pm 4^{b}$ & $86 \pm 3^{b}$ & $<0.0001$ \\
\hline & Amplitude & - & $13 \pm 4$ & $25 \pm 5$ & - & - & NS \\
\hline & Acrophase & - & $15.4 \pm 1.2$ & $13.6 \pm 0.8$ & - & - & NS \\
\hline \multirow[t]{3}{*}{ Per2 } & Mesor & $100 \pm 3^{a}$ & $98 \pm 2^{a}$ & $113 \pm 4^{b}$ & $117 \pm 5^{b}$ & $113 \pm 2^{b}$ & $<0.0001$ \\
\hline & Amplitude & $28 \pm 5$ & $12 \pm 3$ & $20 \pm 6$ & $18 \pm 6$ & $19 \pm 3$ & NS \\
\hline & Acrophase & $16.3 \pm 0.6$ & $14.9 \pm 0.9$ & $14.9 \pm 1.1$ & $14.5 \pm 1.3$ & $15.2 \pm 0.7$ & NS \\
\hline \multirow[t]{3}{*}{ Cry1 } & Mesor & $100 \pm 2^{a}$ & $100 \pm 2^{a}$ & $134 \pm 3^{b}$ & $95 \pm 2^{a}$ & $114 \pm 2^{c}$ & $<0.0001$ \\
\hline & Amplitude & $14 \pm 3$ & $16 \pm 3$ & $12 \pm 4$ & $11 \pm 3$ & $11 \pm 3$ & NS \\
\hline & Acrophase & $18.6 \pm 0.8$ & $19.8 \pm 0.9$ & $21.3 \pm 1.5$ & $18.2 \pm 1.1$ & $17.1 \pm 1.1$ & NS \\
\hline \multirow[t]{3}{*}{ Cry2 } & Mesor & $100 \pm 2^{a}$ & $81 \pm 2^{b}$ & $114 \pm 3^{c}$ & $85 \pm 2^{b}$ & $135 \pm 4^{d}$ & $<0.0001$ \\
\hline & Amplitude & - & $8 \pm 3$ & $10 \pm 4$ & - & - & NS \\
\hline & Acrophase & - & $17.5 \pm 1.3$ & $19.6 \pm 1.5$ & - & - & NS \\
\hline \multirow[t]{3}{*}{ Rev-erb $\alpha$} & Mesor & $100 \pm 2^{a}$ & $121 \pm 3^{b}$ & $149 \pm 3^{c}$ & $124 \pm 3^{b}$ & $128 \pm 3^{b}$ & $<0.0001$ \\
\hline & Amplitude & $17 \pm 2^{a, c}$ & $23 \pm 4^{a, c, d}$ & $33 \pm 5^{d, b}$ & $26 \pm 5^{c, b}$ & $13 \pm 5^{a}$ & $<0.05$ \\
\hline & Acrophase & $8.5 \pm 0.6^{a, c}$ & $8.1 \pm 0.7^{a, c}$ & $7.0 \pm 0.6^{c}$ & $9.3 \pm 0.7^{a, b}$ & $11.0 \pm 1.3^{b}$ & $<0.05$ \\
\hline \multirow[t]{3}{*}{ Ror $\alpha$} & Mesor & $100 \pm 5^{a}$ & $164 \pm 11^{\mathrm{b}, \mathrm{c}}$ & $175 \pm 10^{b}$ & $138 \pm 8^{c}$ & $171 \pm 13^{b}$ & $<0.0001$ \\
\hline & Amplitude & - & $43 \pm 16$ & - & - & - & - \\
\hline & Acrophase & - & $15.2 \pm 1.4^{a}$ & - & - & - & - \\
\hline
\end{tabular}

Values are mean \pm S.E.M. and expressed relative to the mesor value in the non-pregnant group (set at 100). Acrophase is expressed as clock time. Within each group, values without a common notation differ significantly $(P<0.05$; one-way ANOVA and Fisher's LSD test).

http://joe.endocrinology-journals.org DOI: $10.1530 / \mathrm{JOE}-15-0405$
(C) 2016 Society for Endocrinology Printed in Great Britain
Published by Bioscientifica Ltd 

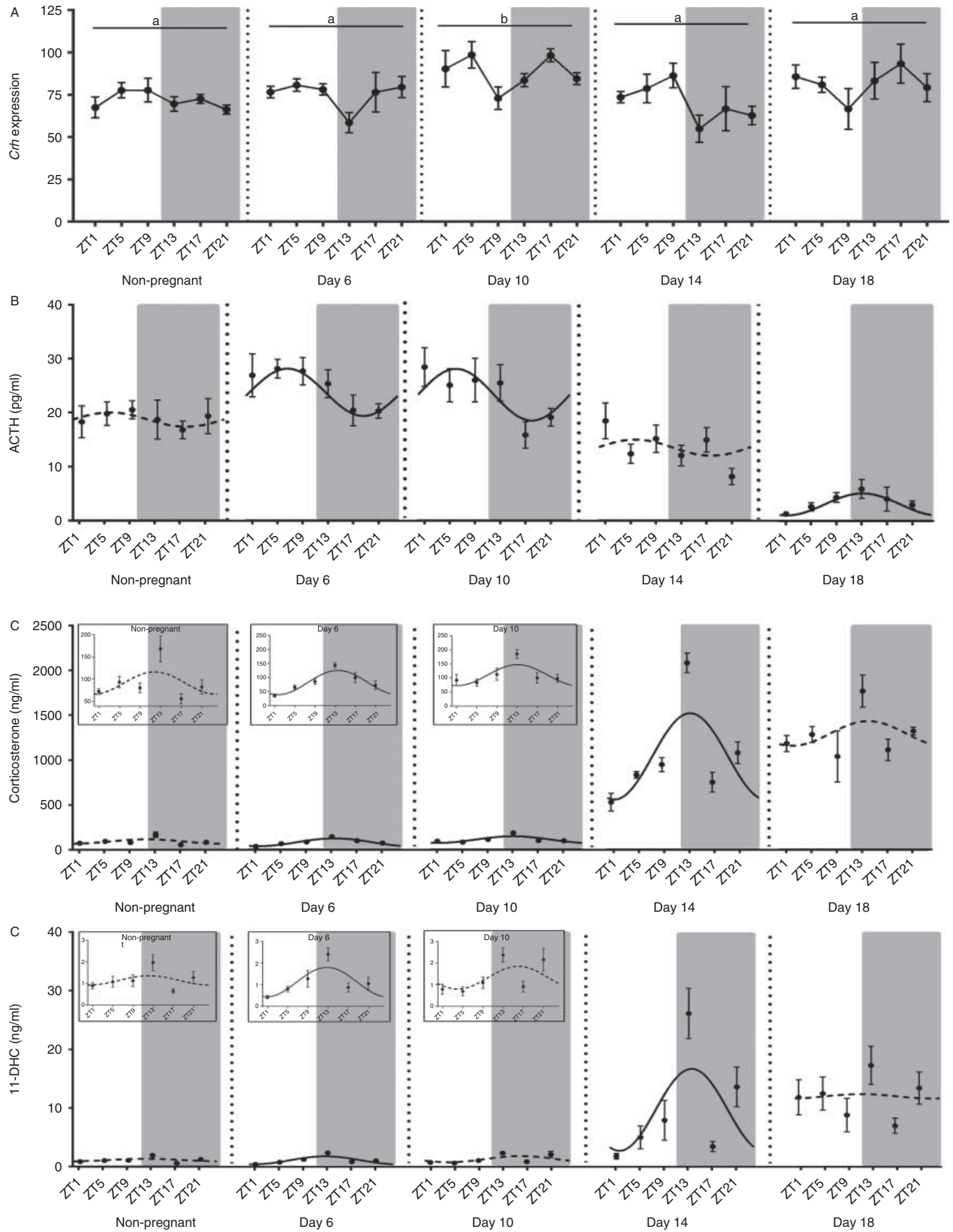

Figure 3

Hypothalamic expression of (A) Crh and plasma concentrations of (B) ACTH $(\mathrm{pg} / \mathrm{ml}),(C)$ corticosterone $(\mathrm{ng} / \mathrm{ml})$ and (D) 11-DHC $(\mathrm{ng} / \mathrm{ml})$ at ZT1, ZT5, ZT9, ZT13, ZT17 and ZT21 in non-pregnant and pregnant mice on days $6,10,14$ and 18 . Values are mean \pm s.E.M. ( $n=6-8 /$ group). Gray shading represents the dark phase of the light cycle. For Crh expression, cosinor curves are not shown since this analysis showed no statistical significance at any stage.
For these profiles, values without a common notation differ significantly $(P<0.001$; two-way ANOVA and post hoc LSD test). For plasma corticosterone and 11-DHC, insets are included for non-pregnant levels and days 6 and 10 of pregnancy to show the same data on a reduced $y$-axis scale. The best-fit curve derived from cosinor analysis is shown as a solid line when significant $(P<0.05)$ and as a dashed line when non-significant. 
Table 4 Values of $r^{2}$ derived from cosinor analyses of anterior hypothalamic expression of Crh mRNA, plasma ACTH, corticosterone and 11-DHC

\begin{tabular}{l} 
Gene/Hormone \\
\hline Crh \\
ACTH \\
Corticosterone \\
$11-\mathrm{DHC}$
\end{tabular}

\begin{tabular}{c}
\hline Non-pregnant \\
\hline $0.032(\mathrm{NS})$ \\
$0(\mathrm{NS})$ \\
$0.076(P=0.089)$ \\
$0(\mathrm{NS})$
\end{tabular}

\begin{tabular}{l}
\multicolumn{1}{c}{ Day 6} \\
\hline $0.037(\mathrm{NS})$ \\
$0.160(P<0.05)$ \\
$0.435(P<0.001)$ \\
$0.243(P<0.001)$ \\
\hline
\end{tabular}

\begin{tabular}{c}
\hline \multicolumn{1}{c}{ Day 10} \\
\hline $0(\mathrm{NS})$ \\
$0.121(P<0.05)$ \\
$0.171(P=0.004)$ \\
$0.081(\mathrm{NS})$
\end{tabular}

\begin{tabular}{c}
\hline Day 14 \\
\hline $0.089(\mathrm{NS})$ \\
$0(\mathrm{NS})$ \\
$0.344(P<0.001)$ \\
$0.165(P<0.05)$ \\
\hline
\end{tabular}

\begin{tabular}{c}
\hline Day 18 \\
\hline $0.002(N S)$ \\
$0.145(P<0.05)$ \\
$0(N S)$ \\
$0(N S)$ \\
\hline
\end{tabular}

Relevant $P$ values are shown in parentheses unless non-significant (NS).

with a dramatic decline in levels observed by day 18 (83\% lower than non-pregnant levels, Fig. 3B).

Cosinor analysis showed highly significant circadian variation for plasma ACTH on days 6, 10 and 18 of pregnancy (see Table 4 for $r^{2}$ and $P$ values). The mesor, amplitude and acrophase for these days of gestation are presented in Table 5. The mesor levels of plasma ACTH increased 1.3-fold between diestrus and early gestation (days 6 and 10), before decreasing by $43 \%$ on day 14 and a further $77 \%$ on day $18(P<0.0001$; Fig. $3 B)$. While the amplitude did not change across pregnancy, the acrophase was delayed $\sim 7 \mathrm{~h}$ by day 18 of pregnancy $(P<0.001$; Table 5).

\section{Plasma corticosterone}

Plasma corticosterone levels varied with time of day $(P<0.001$, ANOVA), with all profiles characterized by a daily peak soon after lights off at ZT13 (Fig. 3C). Pregnancy had a dramatic effect on the absolute levels of plasma corticosterone $(P<0.001)$, with overall increases observed between non-pregnant levels and day 14 (11-fold) and day 18 (14-fold) of pregnancy. There was also a significant time of day $\times$ stage of pregnancy interaction $(P<0.05)$, indicating that the circadian variation in plasma corticosterone was influenced by the stage of pregnancy.

Cosinor analysis showed highly significant circadian variation for plasma corticosterone on days 6,10 and 14 of pregnancy (see Table 4 for $r^{2}$ and $P$ values). While there was only a trend for cosinor rhythmicity prior to pregnancy, clear time-of-day variation existed within this group $(P<0.05$, ANOVA) with a 2.3 -fold increase in levels between ZT1 and ZT13 $(P<0.01$, unpaired $t$-test). Interestingly, rhythmic variation in corticosterone appeared to be lost by day 18 , with high levels maintained across the full $24 \mathrm{~h}$ period. The derived mesor, amplitude and acrophase for plasma corticosterone at each stage of gestation are presented in Table 5. The mesor level of plasma corticosterone was similar before and on days 6 and 10 of pregnancy, but had increased by approximately tenfold 4 days later (on day $14 ; P<0.001$ ) and by another 1.2 -fold by day 18 ( $P<0.001$; Fig. $3 C)$. The amplitude of the corticosterone rhythm displayed a similar pattern $(P<0.001)$, remaining unchanged up to day 10 but then increasing dramatically (almost 20-fold) by day 14 before falling by day 18 (but still 5.5 -fold greater than before pregnancy) (Fig. 3C). The acrophase of the corticosterone rhythm remained unchanged across pregnancy (Fig. 3C).

Table 5 Mesor, amplitude and acrophase derived from cosinor analyses of plasma ACTH, corticosterone and 11-DHC and calculated corticosterone:11-DHC ratio across pregnancy

\begin{tabular}{|c|c|c|c|c|c|c|c|}
\hline & & Non-pregnant & Day 6 & Day 10 & Day 14 & Day 18 & $\boldsymbol{P}$ \\
\hline \multirow[t]{3}{*}{ ACTH } & Mesor (pg/ml) & $18.7 \pm 1.1^{\mathrm{a}}$ & $23.8 \pm 1.0^{b}$ & $23.3 \pm 1.2^{b}$ & $13.5 \pm 1.0^{c}$ & $3.1 \pm 0.5^{d}$ & $<0.0001$ \\
\hline & Amplitude (pg/ml) & - & $4.4 \pm 1.4$ & $4.8 \pm 1.7$ & - & $2.0 \pm 0.7$ & NS \\
\hline & Acrophase & - & $6.6 \pm 1.3^{a}$ & $6.0 \pm 1.4^{a}$ & - & $13.1 \pm 1.5^{b}$ & $<0.001$ \\
\hline \multirow[t]{3}{*}{ Corticosterone } & Mesor (ng/ml) & $91.5 \pm 7.8^{\mathrm{a}}$ & $81.3 \pm 5.0^{\mathrm{a}}$ & $110.8 \pm 7.7^{a}$ & $1038.2 \pm 65.9^{b}$ & $1293.9 \pm 69.5^{c}$ & $<0.0001$ \\
\hline & Amplitude (ng/ml) & - & $43.4 \pm 7.2^{\mathrm{a}}$ & $37.2 \pm 11.0^{a}$ & $481.5 \pm 93.3^{\mathrm{b}}$ & - & $<0.0001$ \\
\hline & Acrophase & - & $13.5 \pm 0.6$ & $13.1 \pm 1.1$ & $13.1 \pm 0.7$ & - & NS \\
\hline \multirow[t]{3}{*}{ 11-DHC } & Mesor (ng/ml) & $1.1 \pm 0.1^{a}$ & $1.1 \pm 0.1^{a}$ & $1.3 \pm 0.2^{\mathrm{a}}$ & $9.7 \pm 1.5^{b}$ & $12.0 \pm 1.2^{b}$ & $<0.0001$ \\
\hline & Amplitude (ng/ml) & - & $0.7 \pm 0.2^{a}$ & - & $6.9 \pm 2.1^{b}$ & - & $<0.001$ \\
\hline & Acrophase & - & $12.8 \pm 0.9$ & - & $13.6 \pm 1.1$ & - & NS \\
\hline $\begin{array}{l}\text { Ratio corticosterone: } \\
\text { 11-DHC }\end{array}$ & & $88 \pm 14^{a}$ & $86 \pm 11^{a}$ & $118 \pm 19^{a}$ & $205 \pm 36^{b}$ & $140 \pm 26^{a}$ & $<0.05$ \\
\hline
\end{tabular}

Values are mean \pm s.E.M. Within each group, values without a common notation differ significantly $(P<0.05$; one-way ANOVA and Fisher's LSD test).

http://joe.endocrinology-journals.org DOI: $10.1530 / \mathrm{JOE}-15-0405$
(C) 2016 Society for Endocrinology Printed in Great Britain
Published by Bioscientifica Ltd. 


\section{Plasma 11-DHC}

Plasma levels of the corticosterone metabolite 11-DHC generally paralleled the circadian pattern of corticosterone, varying with time of day $(P<0.001$, ANOVA) and showing peak levels soon after lights off. Plasma 11-DHC levels also varied with stage of pregnancy $(P<0.001$; Fig. 3D), and there was a significant interaction between time of day and stage of pregnancy $(P<0.05)$.

As with plasma corticosterone, cosinor analysis showed highly significant circadian variation for plasma 11-DHC on days 6 and 14 of pregnancy (see Table 4 for $r^{2}$ and $P$ values), with a trend for rhythmicity evident on day 10 . The mesor level remained relatively stable until day 10 but then increased more than 7-fold by days 14 and 18 $(P<0.001$; Table 5, Fig. 3D). The amplitude of the plasma 11-DHC rhythm increased tenfold between days 6 and 14, but by day 18 , rhythmic variation in 11-DHC was effectively absent (Fig. 3D).

\section{Ratio of corticosterone:11-DHC}

The ratio of corticosterone:11-DHC remained relatively stable until day 10 but then increased by day 14 (1.75-fold; $P=0.002$ ), before returning to non-pregnant levels by day 18 (Table 5, Fig. 4).

\section{Correlations between plasma corticosterone and hypothalamic clock genes and plasma ACTH}

We also explored possible relationships between clock gene expression and circulating corticosterone

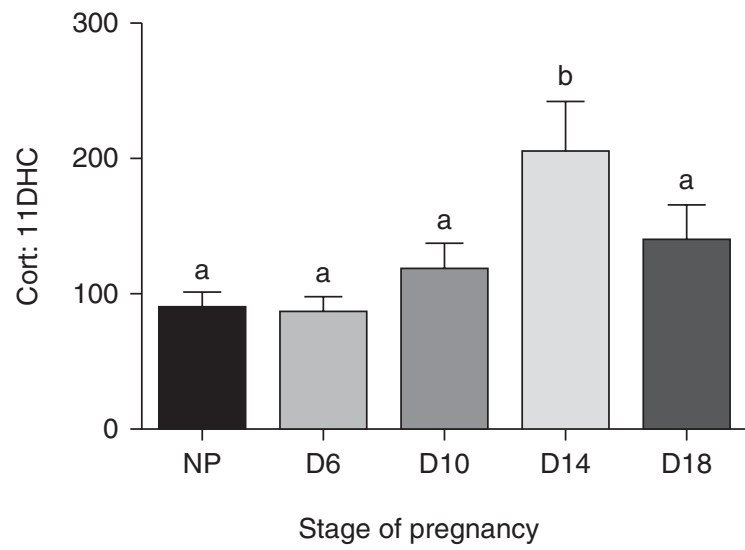

Figure 4

Ratio of corticosterone:11-DHC in maternal plasma from non-pregnant and pregnant mice on days $6,10,14$ and 18 . Values are mean \pm s.E.M. ( $n=39-48 /$ group). Values without a common notation differ significantly $(P=0.002$; one-way ANOVA and post hoc LSD test).
(Supplementary Table 1, see section on supplementary data given at the end of this article). Thus, plasma corticosterone was negatively correlated with hypothalamic Bmal1 (on days 6 and 14 of pregnancy), Clock (on days 6, 10, 14 and 18 of pregnancy) and Cry2 (on day 14 of pregnancy). In contrast, a positive association was observed between plasma corticosterone and Ror $\alpha$ (on day 6 of pregnancy). Finally, plasma ACTH was positively correlated with corticosterone only on day 10 of pregnancy.

\section{Discussion}

This study demonstrates for the first time that the hypothalamic expression of the core (Clock, Bmal1, Per1, Per2, Cry1 and Cry2) and accessory (Rev-erb $\alpha$ and Ror $\alpha$ ) clock genes changes markedly during pregnancy in the mouse. Our data also characterize substantial shifts in absolute levels and circadian variation of plasma corticosterone and its key metabolite, 11-DHC, after mid-gestation. Importantly, the marked elevation in circulating glucocorticoids was not associated with comparable changes in either hypothalamic Crh mRNA expression or plasma ACTH, suggesting that higher corticosterone levels may be driven by factors beyond the conventional HPA axis (e.g. placental trophic support for the adrenal).

Clock genes are a set of rhythmically expressed transcription factors that drive rhythms in downstream genes directly involved in numerous physiological processes (Reppert \& Weaver 2002, Hastings et al. 2007). Hypothalamic expression of all clock genes changed with the onset and progression of pregnancy, with clear effects on the mesor of each clock gene (an indicative measure of overall expression) evident by mid-gestation. Specifically, by day 10 of pregnancy, the mesor of each clock gene was elevated above pre-pregnancy levels and, in the majority of cases, expression was highest at this stage (up to 1.5fold). These increases in clock gene expression suggest a major shift in the function of the central clock in pregnancy, presumably to drive gestational adaptations in maternal behavior and physiology. Together with our previous findings of pregnancy-induced changes to liver clock genes late in rat gestation (Wharfe et al. 2011), the present data suggest that widespread alterations to the circadian system are a feature of maternal physiological adaptations to pregnancy. Further studies are required to determine the mechanisms by which pregnancy-induced changes in central and peripheral clocks occur, but a role for the highly dynamic hormonal milieu of pregnancy seems likely. Indeed, a number of clock genes contain

Published by Bioscientifica Ltd. 
estrogen and progesterone response elements within their promoter regions (Nakamura et al. 2005, He et al. 2007, Nakamura et al. 2010), and ER $\alpha, \mathrm{ER} \beta$ and PR are expressed within the SCN (Blaustein \& Wade 1978, Blaustein et al. 1988, Vida et al. 2008). Previous studies have also shown that clock gene expression is influenced by estradiol in the SCN (Nakamura et al. 2001, Nakamura et al. 2005) and by progesterone in the uterus (He et al. 2007, Nakamura et al. 2010, Rubel et al. 2012). Moreover, the clock gene expression can be regulated by corticosterone, as glucocorticoid response elements are present within the promoter regions of Per1, Per2 and Rev-erb $\alpha$ (Balsalobre et al. 2000, Yamamoto et al. 2005, So et al. 2009). However, corticosterone is unlikely to drive pregnancy-induced changes in the central clock directly since glucocorticoid receptor expression is absent or minimal within the SCN (Rosenfeld et al. 1988, Balsalobre et al. 2000, Kalsbeek et al. 2012).

In contrast to the changes in the hypothalamic expression of the clock genes, that of $\mathrm{Crh}$ remained relatively stable across pregnancy. Similarly, while $\mathrm{Crh}$ expression showed a trend for overall time-of-day variation, this did not match the conventional cosinor pattern observed for the clock genes. These observations may appear surprising given that ablation studies (both anatomical and transgenic) have highlighted the importance of the SCN in the regulation of the diurnal secretion of corticosterone (Moore \& Eichler 1972, Sellix et al. 2006). Interestingly, while a previous study also observed arrhythmic hypothalamic Crh mRNA expression in the mouse, rhythmic expression of $\mathrm{Crh}$ heteronuclear (hn) RNA was detected, indicative of circadian variation in $\mathrm{Crh}$ at this pre-processing stage (Watts et al. 2004). This suggests that hypothalamic Crh expression at the heteronuclear RNA level may be influenced by the rhythmic expression of SCN clock genes, but this is obscured by other regulatory factors at the mRNA level. Moreover, the central clock also appears to influence the HPA axis independently of $\mathrm{CRH}$, possibly via changes in adrenocortical sensitivity to ACTH across the circadian day (Kaneko et al. 1981). This effect is mediated centrally via the autonomic nervous system (ANS)(Buijs et al. 1999).

Our data also show for the first time that the full circadian profile of maternal corticosterone increases dramatically after mid-gestation in the mouse (i.e. on days 14 and 18). Elevation of the full circadian profile of glucocorticoids has previously been reported for human (Patrick et al. 1980) and rat pregnancy (Atkinson \& Waddell 1995), but the magnitude of the increase observed here in the mouse is several fold greater.
Moreover, these higher levels of corticosterone occurred even though absolute levels of plasma ACTH fell markedly over the same period. This apparent decoupling of circulating ACTH and corticosterone suggests that factors outside the conventional HPA axis influence plasma corticosterone in pregnancy. For example, enhanced adrenal responsiveness appears to drive increased maternal corticosterone levels after mid-gestation in the rat (Atkinson \& Waddell 1995), an effect likely mediated via rising estrogen levels (Atkinson \& Waddell 1997, Figueiredo et al. 2007). Other 'non-HPA axis' factors that could enhance maternal levels of corticosterone include a fall in its metabolic clearance rate due to higher plasma corticosteroid-binding globulin (CBG) levels (Gala \& Westphal 1967, Douglas et al. 2003) or a contribution from the fetal adrenal. The latter is consistent with activation of the fetal HPA axis late in development (Cottrell et al. 2012) and the coincident loss of the placental glucocorticoid barrier (Brown et al. 1996), which may also explain the loss of maternal corticosterone rhythmicity by day 18 of gestation. Finally, a number of studies have suggested that the placenta could provide direct trophic support to the adrenal, thereby stimulating adrenal corticosterone secretion independently of the HPA axis (Waddell 1993, Waddell \& Burton 1993).

Given the established links between the central clock and adrenal sensitivity (via the ANS) (Buijs et al. 1999) and with the HPA axis (Nader et al. 2010), one might expect a positive relationship between hypothalamic clock gene expression and corticosterone levels. On the contrary, our data show that there was no such association for the majority of the clock genes, and where a relationship was observed (three of eight genes), it was predominantly negative. The single exception was for Ror $\alpha$, which showed a positive association with corticosterone on day 6 of gestation. Further studies are required to determine whether the multiple regulatory pathways that link the central clock and the adrenal cortex (e.g. via adrenal sensitivity and regulation of clock gene expression indirectly by corticosterone) obscure such correlations.

The biologically inert metabolite of corticosterone, 11-DHC, was detectable in plasma at all stages of pregnancy but at much lower concentrations than corticosterone. For the first time, we have shown that throughout pregnancy, the circadian profiles of 11-DHC generally paralleled the corresponding corticosterone profiles, including the apparent loss of rhythmicity on day 18. The ratio of corticosterone:11-DHC increased substantially on day 14 , possibly due to greater plasma

Published by Bioscientifica Ltd 
CBG binding of corticosterone and an associated reduction in the proportion metabolized to 11-DHC (Barlow et al. 1974, 1975). This conversion is catalyzed by the $11 \beta$-hydroxysteroid dehydrogenase enzymes

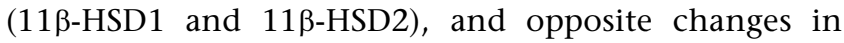
their expression occur in the two placental zones late in rodent pregnancy (Mark et al. 2009). These changes in enzyme expression are likely to influence total $11 \beta-H S D$ enzymatic capacity and thereby impact on the plasma corticosterone:11-DHC ratio near term.

It is possible that alterations to the circadian system during pregnancy, such as those seen in the central clock and the HPA axis, may contribute to gestational adaptations in maternal metabolism. Indeed, the central clock is known to influence peripheral tissue clocks via neural and humoral signals (Hastings et al. 2007). Furthermore, links between the clock gene network and metabolism (Froy 2010) indicate that changes to circadian rhythms of clock gene expression in peripheral tissues regulate the expression of downstream genes governing physiological processes including glucose and lipid metabolism, both of which are adapted in pregnancy (Suman Rao et al. 2013). For example, the steady increase in the absolute levels of hypothalamic Bmal1 across gestation may contribute to the sustained availability of nutrients from peripheral tissue stores by driving altered neural and/or humoral signals via the PVN (Kalsbeek et al. 2006). Previous studies have shown that hepatic Bmal1 is particularly important in relation to the regulation of hepatic glucose metabolism (Lamia et al. 2008), while Rev-erb $\alpha$ plays a key role in lipid metabolism within the liver and adipose tissue (Delezie et al. 2012). Accordingly, it will be of interest to explore how changes in the central and peripheral circadian clocks influence maternal metabolic adaptations in pregnancy.

In conclusion, this study shows that the central circadian clock undergoes marked adaptations with the onset and progression of mouse pregnancy. Importantly, neither clock genes nor plasma ACTH levels appear to drive the dramatic increase in the maternal glucocorticoid levels observed after mid-gestation. The pregnancyinduced changes in the central circadian clock and the HPA axis likely promote pregnancy success by driving maternal physiological adaptations to meet the metabolic demands of fetal growth.

\section{Supplementary data}

This is linked to the online version of the paper at http://dx.doi.org/10.1530/ JOE-15-0405.

\section{Declaration of interest}

The authors declare that there is no conflict of interest that could be perceived as prejudicing the impartiality of the research reported.

\section{Funding}

This research did not receive any specific grant from any funding agency in the public, commercial or not-for-profit sector.

\section{Acknowledgements}

The authors are grateful to Professor Hugh Barrett (the University of Western Australia) for his advice on cosinor analysis.

\section{References}

Atkinson HC \& Waddell BJ 1995 The hypothalamic-pituitary-adrenal axis in rat pregnancy and lactation: circadian variation and interrelationship of plasma adrenocorticotrophin and corticosterone. Endocrinology 136 512-520. (doi:10.1210/endo.136.2.7835284)

Atkinson HC \& Waddell BJ 1997 Circadian variation in basal plasma corticosterone and adrenocorticotropin in the rat: sexual dimorphism and changes across the estrous cycle. Endocrinology $1383842-3848$. (doi:10.1210/endo.138.9.5395)

Balsalobre A, Brown SA, Marcacci L, Tronche F, Kellendonk C, Reichardt HM, Schutz G \& Schibler U 2000 Resetting of circadian time in peripheral tissues by glucocorticoid signalling. Science $\mathbf{2 8 9}$ 2344-2347. (doi:10.1126/science.289.5488.2344)

Barlow SM, Morrison PJ \& Sullivan FM 1974 Plasma corticosterone levels during pregnancy in the mouse: the relative contributions of the adrenal glands and foeto-placental units. Journal of Endocrinology 60 473-483. (doi:10.1677/joe.0.0600473)

Barlow SM, Morrison PJ \& Sullivan FM 1975 Effects of acute and chronic stress on plasma corticosterone levels in the pregnant and non-pregnant mouse. Journal of Endocrinology 66 93-99. (doi:10.1677/joe.0.0660093)

Blaustein JD \& Wade GN 1978 Progestin binding by brain and pituitary cell nuclei and female rat sexual behavior. Brain Research 140 360-367. (doi:10.1016/0006-8993(78)90469-9)

Blaustein JD, King JC, Toft DO \& Turcotte J 1988 Immunocytochemical localization of estrogen-induced progestin receptors in guinea pig brain. Brain Research 474 1-15. (doi:10.1016/0006-8993(88)90664-6)

Brown R, Diaz R, Robson A, Kotelevtsev Y, Mullins J, Kaufman M \& Seckl J 1996 The ontogeny of $11 \beta$-hydroxysteroid dehydrogenase type 2 and mineralocorticoid receptor gene expression reveal intricte control of glucocorticoid action in development. Endocrinology 137 794-797. (doi:10.1210/endo.137.2.859383)

Buijs RM, Wortel J, Van Heerikhuize JJ, Feenstra MG, Ter Horst GJ, Romijn HJ \& Kalsbeek A 1999 Anatomical and functional demonstration of a multisynaptic suprachiasmatic nucleus adrenal (cortex) pathway. European Journal of Neuroscience 11 1535-1544. (doi:10.1046/ j.1460-9568.1999.00575.x)

Caligioni C 2009 Assessing reproductive status/stages in mice. Current Protocols in Neuroscience 48(4I) A4I.1-A4I.8. Appendix 4I.

Cottrell EC, Holmes MC, Livingstone DE, Kenyon CJ \& Seckl JR 2012 Reconciling the nutritional amd glucocorticoid hypotheses of fetal programming. FASEB Journal 26 1866-1874. (doi:10.1096/fj.12-203489)

Delezie J, Dumont S, Dardente H, Oudart H, Grechez-Cassiau A, Klosen P, Teboul M, Delaunay F, Pevet P \& Challet E 2012 The nuclear receptor $\mathrm{REV}-\mathrm{ERB} \alpha$ is required for the daily balance of carbohydrate and lipid metabolism. FASEB Journal 26 3321-3335. (doi:10.1096/fj.12-208751)

Douglas AJ, Brunton PJ, Bosch OJ, Russell JA \& Neumann ID 2003 Neuroendocrine responses to stress in mice: hyporesponsiveness 
in pregnancy and parturition. Endocrinology 144 5268-5276. (doi:10.1210/en.2003-0461)

Figueiredo HF, Ulrich-Lai YM, Choi DC \& Herman JP 2007 Estrogen potentiates adrenocortical responses to stress in female rats. American Journal of Physiology. Endocrinology and Metabolism 292 E1173-E1182. (doi:10.1152/ajpendo.00102.2006)

Froy O 2010 Metabolism and circadian rhythms - implications for obesity. Endocrine Reviews 31 1-24. (doi:10.1210/er.2009-0014)

Gala RR \& Westphal U 1967 Corticosteroid-binding activity in serum of mouse, rabbit and guinea pig during pregnancy and lactation: possible involvement in the initiation of lactation. Acta Endocrinologica 55 47-61. (doi:10.1530/acta.0.0550047)

Hastings M, O'Neill J \& Maywood ES 2007 Circadian clocks: regulators of endocrine and metabolic rhythms. Journal of Endocrinology 195 187-198. (doi:10.1677/JOE-07-0378)

He P-J, Hirata M, Yamauchi N \& Hattori M 2007 Up-regulation of Per1 expression by estradiol and progesterone in the rat uterus. Journal of Endocrinology 194 511-519. (doi:10.1677/JOE-07-0172)

Kalsbeek A, Palm IF, La Fleur SE, Scheer FA, Perreau-Lenz S, Ruiter M, Kreier F, Cailotto C \& Buijs RM 2006 SCN outputs and the hypothalamic balance of life. Journal of Biological Rhythms 21 458-469. (doi:10.1177/0748730406293854)

Kalsbeek A, Van der Spek R, Lei J, Endert E, Buijs RM \& Fliers E 2012 Circadian rhythms in the hypothalamo-pituitary-adrenal (HPA) axis. Molecular and Cellular Endocrinology 349 20-29. (doi:10.1016/j.mce. 2011.06.042)

Kaneko M, Kaneko K, Shinsako J \& Dallman MF 1981 Adrenal sensitivity to adrenocorticotropin varies diurnally. Endocrinology 109 70-75. (doi:10.1210/endo-109-1-70)

Lamia KA, Storch KF \& Weitz CJ 2008 Physiological significance of a peripheral tissue circadian clock. PNAS 105 15172-15177. (doi:10.1073/pnas.0806717105)

Mark PJ, Augustus S, Lewis JL, Hewitt DP \& Waddell BJ 2009 Changes in placental glucocorticoid barrier during rat pregnancy: impact on placental corticosterone levels and regulation by progesterone. Biology of Reproduction 80 1209-1215. (doi:10.1095/biolreprod.108.073650)

Moore RY \& Eichler VB 1972 Loss of a circadian adrenal corticosterone rhythm following suprachiasmatic lesions in the rat. Brain Research 42 201-206. (doi:10.1016/0006-8993(72)90054-6)

Nader N, Chrousos GP \& Kino T 2010 Interactions of the circadian CLOCK system and the HPA axis. Trends in endocrinology and metabolism 21 277-286. (doi:10.1016/j.tem.2009.12.011)

Nakamura TJ, Shinohara K, Funabashi T \& Kimura F 2001 Effect of estrogen on the expression of Cry1 and Cry 2 mRNAs in the suprachiasmatic nucleus of female rats. Neuroscience Research 41 251-255. (doi:10.1016/ S0168-0102(01)00285-1)

Nakamura TJ, Moriya T, Inoue S, Shimazoe T, Watanabe S, Ebihara S \& Shinohara K 2005 Estrogen differentially regulates expression of Per1 and Per2 gene between central and peripheral clocks and between reproductive and nonreproductive tissues in female rats. Journal of Neuroscience Research 82 622-630. (doi:10.1002/jnr.20677)

Nakamura TJ, Sellix MT, Kudo T, Nakao N, Yoshimura T, Ebihara S, Colwell CS $\&$ Block GD 2010 Influence of the estrous cycle on clock gene expression in reproductive tissues: Effects of fluctuating ovarian steroid hormone levels. Steroids 75 203-212. (doi:10.1016/j.steroids.2010.01.007)

Patrick J, Challis J, Campbell K, Carmichael L, Natale R \& Richardson B 1980 Circadian rhythms in maternal plasma cortisol and estriol concentrations at 30 to 31,34 to 35 , and 38 to 39 weeks gestational age. American Journal of Obstetrics and Gynecology 136 325-334.

Quennell JH, Howell CS, Roa J, Augustine RA, Grattan DR \& Anderson GM 2011 Leptin deficiency and diet-induced obesity reduce hypothalamic kisspeptin expression in mice. Neuroendocrinology 152 1541-1550. (doi:10.1210/en.2010-1100)

Reppert SM \& Weaver DR 2002 Coordination of circadian timing in mammals. Nature 418 935-941. (doi:10.1038/nature00965)

Rosenfeld P, Van Eekelen JA, Levine S \& De Kloet ER 1988 Ontogeny of the type 2 glucocorticoid receptor in discrete brain regions: an immunocytochemical study. Brain Research. Developmental Brain Research 42 119-127. (doi:10.1016/0165-3806(88)90207-6)

Rubel CA, Lanz RB, Kommagani R, Franco HL, Lydon JP \& DeMayo FJ 2012 Research resource: genome-wide profiling of progesterone receptor binding in the mouse uterus. Molecular Endocrinology 26 1428-1442. (doi:10.1210/me.2011-1355)

Schrader JA, Nunez AA \& Smale L 2010 Changes in and dorsal to the rat suprachiasmatic nucleus during early pregnancy. Neuroscience $\mathbf{1 7 1}$ 513-523. (doi:10.1016/j.neuroscience.2010.08.057)

Sellix MT, Egli M, Poletini MO, McKee DT, Bosworth MD, Fitch CA \& Freeman ME 2006 Anatomical and functional characterization of clock gene expression in neuroendocrine dopaminergic neurons. American Journal of Physiology. Regulatory, Integrative and Comparative Physiology 290 R1309-R1323. (doi:10.1152/ajpregu.00555.2005)

So AY, Bernal TU, Pillsbury ML, Yamamoto KR \& Feldman BJ 2009 Glucocorticoid regulation of the circadian clock modulates glucose homeostasis. PNAS 106 17582-17587. (doi:10.1073/pnas.0909733106)

Spiga F, Walker JJ, Terry JR \& Lightman SL 2014 HPA axis-rhythms. Comprehensive Physiology 4 1273-1298. (doi:10.1002/cphy.c140003)

Suman Rao PN, Shashidhar A \& Ashok C 2013 In utero fuel homeostasis: lessons for a clinician. Indian Journal of Endocrinology and Metabolism $\mathbf{1 7}$ 60-68. (doi:10.4103/2230-8210.107851)

Vandesompele J, De Preter K, Pattyn F, Poppe B, Van Roy N, De Paepe A \& Speleman F 2002 Accurate normalization of real-time quantitative RTPCR data by geometric averaging of multiple internal control genes. Genome Biology 3 1-12. (doi:10.1186/gb-2002-3-7-research0034)

Varcoe TJ, Wight N, Voultsios A, Salkeld MD \& Kennaway DJ 2011 Chronic phase shifts of the photoperiod throughout pregnancy programs glucose intolerance and insulin resistance in the rat. PLOS ONE 6 e18504. (doi:10.1371/journal.pone.0018504)

Vida B, Hrabovszky E, Kalamatianos T, Coen CW, Liposits Z \& Kalló I 2008 Oestrogen receptor $\alpha$ and $\beta$ immunoreactive cells in the suprachiasmatic nucleus of mice: distribution, sex differences and regulation by gonadal hormones. Journal of Neuroendocrinology 20 1270-1277. (doi:10.1111/j.1365-2826.2008.01787.x)

Waddell BJ 1993 The placenta as hypothalamus and pituitary: possible impact on maternal and fetal adrenal function. Reproduction, Fertility, and Development 5 479-497. (doi:10.1071/RD9930479)

Waddell BJ \& Burton PJ 1993 Release of bioactive ACTH by perifused human placenta at early and late gestation. Journal of Endocrinology $\mathbf{1 3 6}$ 345-353. (doi:10.1677/joe.0.1360345)

Watts AG, Tanimura S \& Sanchez-Watts G 2004 Corticotropin-releasing hormone and arginine vasopressin gene transcription in the hypothalamic paraventricular nucleus of unstressed rats: daily rhythms and their interactions with corticosterone. Endocrinology 145 529-540. (doi:10.1210/en.2003-0394)

Wharfe MD, Mark PJ \& Waddell BJ 2011 Circadian variation in placental and hepatic clock genes in rat pregnancy. Endocrinology 152 3552-3560. (doi:10.1210/en.2011-0081)

Yamamoto T, Nakahata Y, Tanaka M, Yoshida M, Soma H, Shinohara K, Yasuda A, Mamine T \& Takumi T 2005 Acute physical stress elevates mouse Period1 mRNA expression in mouse peripheral tissues via a glucocorticoid-responsive element. Journal of Biological Chemistry 280 42036-42043. (doi:10.1074/jbc.M509600200)

Received in final form 16 December 2015

Accepted 22 December 2015

Accepted Preprint published online 23 December 2015 http://joe.endocrinology-journals.org

DOI: $10.1530 / \mathrm{JOE}-15-0405$
(C) 2016 Society for Endocrinology Printed in Great Britain
Published by Bioscientifica Ltd. 